\title{
Introduction to The Economic Analysis of Civil Law
}

\section{$0.1 \quad$ EFFICIENCY AND WASTE}

A central subject of economics is the question of how a society uses its scarce and disposable resources in such a way that the highest possible degree of need satisfaction is obtained. To the extent that this is actually achieved, an economy is considered to be efficient. Otherwise, resources are utilised wastefully. Since the avoidance of waste is a sensible and important goal for society at large, one of the main aims of normative economics and economic policy theory is to propose regulations and institutions whose existence promotes the efficient use of resources.

The economic analysis of law relates this view to the norms of the legal system. It considers it a legitimate and necessary task of jurisprudence to assess legal norms according to the extent to which they prevent the waste of resources and thus increase efficiency. ${ }^{1}$

\section{EXAMPLE 0.1}

In the Alps, it is the task of the road safety authorities to effectively protect motorists against rockfall. This is done by controlled detonation as well as the installation of steel nets, whilst constantly monitoring the dangerous terrain. The resulting use of resources prevents serious accidents and damage to life and limb. Since the prevention of these accidents is more important to society than saving the avoidance costs, a legal regulation is called for that results in the expenditure of these costs. However, there may be circumstances in which this cost expenditure cannot be justified. The Khyber Pass, which connects Afghanistan with Pakistan, leads through dangerously high mountains. If the same avoidance effort were to be incurred in Afghanistan as in the Alps, this would significantly deplete the budget of the responsible provincial government in a low-income country. It would be a waste to spend almost all state resources on the prevention of these accidents whilst largely ignoring other state tasks. In this case, a legal arrangement enforcing accident prevention costs would be inefficient. It is obvious that a court in a European country would apply a different standard of negligence than one in Afghanistan when assessing the responsible body for the duty of safety on roads. It can also be argued that it is unfair to spend so many resources in one country whilst it seems fair in another. This view makes it clear that avoiding waste is also a dictate of justice, that efficiency and justice can coincide across certain areas.

\footnotetext{
Overviews can be found in Bouckaert B, de Geest G (2000) Encyclopedia of Law and Economics
} and Newman P (1998) New Palgrave Dictionary of Economics and the Law. 


\subsection{CONSEQUENTIALISM AND NON-CONSEQUENTIALISM IN THE ECONOMIC ANALYSIS OF LAW}

If the economic analysis of law judges legal norms by the extent to which they prevent the waste of scarce resources it judges these norms by the consequences they have for members of society. To this extent, it belongs in the realm of so-called consequentialist social theories. ${ }^{2}$ According to these theories, actions and decisions of administrations, courts, but also the actions of individuals are evaluated according to the consequences they cause. This also applies to legal norms.

This distinguishes the economic analysis of the law from ideas according to which the only justification for legal norms is that they have been created constitutionally and that they are neither in need of nor capable of further justification.

It also differs from concepts that see the value of actions and decisions in the action itself, regardless of the consequences that are triggered by the actions. Thus, in the above example, whether it is socially right to protect the users of a road by means of steel nets in mountainous terrain depends solely on the consequences.

However, the economic analysis of law is not limited to consequentialist conceptions of justice. In a liberal society, norms of human coexistence can also spontaneously emerge through the interaction of individuals. Such legal norms are not based on a weighing of consequences. Often, they are not even accessible to a sufficiently precise weighing of consequences. They are, through application of Hayek's famous formula, the result of human action but not of human design. Such rules have proven to be evolutionarily stable, although - in an open society - they could and can be attacked.

They derive their legitimacy from this and not from an impact analysis. The economic analysis of law is also concerned with the formation of such norms and their significance to society and the law. ${ }^{3}$

\subsection{DOUBLE INDIVIDUALISM OF ECONOMIC ANALYSIS}

In most of its fields of application, economic analysis uses normative and methodological individualism. Normative individualism claims that state goals and tasks can only be determined by recourse to the goals and preferences of the members of society. In principle - when ignorance and inexperience are excluded - the members of a society know best what is good for them. The task of the state can at best be to summarise and aggregate these wishes and

\footnotetext{
2 See Sen AK, Williams B (1982) Utilitarianism and Beyond.

3 Cf Sudgen R (1989) Spontaneous Order. Journal of Economic Perspectives 3:85 et seq. Heiner R (1990) Rule-Governed Behaviour in Evolution and Human Society. Constitutional Political Economy 1:19 et seq. Hayek F (1979) Law, Legislation and Liberty. 3 Vols.
} 
goals, but not to develop its own preferences, detached from the preferences of the members of society. If, for example, the state caters to produce goods that individuals do not want, this action would be equally wasteful in terms of economic analysis as immediately putting these resources to waste. In this way, economic analysis differs from corporative, organic and system-theoretical concepts of state and law, insofar as these consider society to be a body independent of the individuals who form it.

The economic analysis is individualistic in a second sense. When predicting the effects of legal norms, it assumes that individuals pursue their own benefit ${ }^{4}$ and are not guided by moral categories or a sense of duty. This often-challenged assumption is an instrument of economic analysis and forecasting. The third chapter describes why this instrument is so often used for forecasting purposes. It is important to understand the character of this assumption as a scientific tool. And just as one does not judge a cook by his pots, one will not judge a science by its instruments, but rather by its results and the accuracy of its forecast. This methodological individualism views a rational and selfishly acting person as the basis for understanding norms and institutions. It assumes that institutions are only suitable for fulfilling their tasks if they work in such a way that the persons acting in them simultaneously support these tasks by pursuing their private advantage. Thus, economic analysis is incompatible with those theories that attempt to describe institutions such as the legal system and organisations like parliaments, enterprises, or parties without recourse to individual behaviour. It also differs from all those historical social and legal theories that postulate the possibility of a thorough understanding of state and society without recourse to individual behaviour. It can be expressed as follows: according to the view of methodological individualism, there is no such thing as the behaviour of systems or institutions, but only behaviour in institutions.

\subsection{BEHAVIOURAL ECONOMICS - TURNING AWAY FROM HOMO ECONOMICUS?}

The methodological individualism with the assumption of rational and selfish acting persons is questioned by the approach of behavioural economics. From the perspective of behavioural economics, the model of homo economicus is unsuitable to realistically capture the complexity of human behaviour. Based on the results of empirical psychological research, behavioural economics shows that people do not behave in a consistently rational, selfish and benefit-maximising manner and are often unable to make rational decisions to pursue their own interests because they are subject to systematic errors in information processing. This leads to deviations from rational behaviour, because they are also subject to weaknesses of will, which in turn leads them to value present enjoyment more highly than the detrimental consequences for the future. Finally, they do not behave in a consistently selfish way, but are

4 Gäfgen G (1983) Entwicklung und Stand der Theorie der Property Rights, Eine kritische Bestandsaufnahme [Development and Current Status of the Property Rights Theory. A Critical Survey]. In: Neumann M (ed.) Ansprüche, Eigentums- und Verfügungsrechte. Schriften des Vereins für Sozialpolitik. pp. 43 et seq. 
prepared to give priority to ideas of justice and fairness, even if this is associated with a personal disadvantage.

The findings of behavioural economics are based on investigations of the actual behaviour of people in empirical studies and especially on experiments with test persons. In light of these findings, the model of homo economicus and with it a large part of economic science seems to be challenged. In particular, the central premise that people are best able to judge for themselves what is good for them seems questionable. The studies and propositions of behavioural economics have accordingly triggered a widespread response and also contain explosive power for the economic analysis of the law. However, the objections to the approaches and methods of behavioural economics have meanwhile also become more obvious. For example, there is criticism that behavioural economics has not developed a theory of human behaviour as an alternative to rational choice. The research methods of behavioural economics, which are based on laboratory experiments, also prove to be problematic if the findings are used too quickly to formulate legal policy postulates. However, it has also become clear that a psychologically (i.e. behaviourally) informed legal economics has triggered and continues to trigger new and important findings.

Of central importance in the debate about turning away from homo economicus is the associated shift towards a system of paternalism and the justification for interventions in the general freedom of action derived from this. If one assumes that people are often incapable of making rational decisions in their own affairs and make decisions that they would regret, it is obvious to justify paternalistic interventions in individual freedom of action, by which wrong decisions of those affected are to be corrected in their own interest. Authoritarian paternalism dictates to those affected what they should want from a higher perspective. In a more moderate form of liberal paternalism, interventions should only take place in order to bring the individual to decisions which he or she would have taken through rational behaviour.

A fundamental departure from the homo economicus model cannot be justified by the results of behavioural economic research. However, it is necessary to consider the findings on systematic weaknesses in information processing and on weak wills by rethinking and, if necessary, developing legal regulations further. In strictly limited exceptional cases, corrections through intervention in individual freedom of action may also be considered.

\subsection{ECONOMIC ANALYSIS AND "INSTITUTIONAL CHOICE"}

The economic analysis of law is embedded in a stream of economic research, in which the economic approach is applied to many areas that were previously reserved for other sciences. For example, the performance and failures of organisations such as political parties, associations, bureaucracies, companies, or state organs are examined with the same methodological approach that has traditionally been used to analyse the market and cases of market failure. Common to all these investigations is methodological individualism, the assumption of the existence of resource scarcity and the assertion that it is a reasonable goal to use scarce resources efficiently. In particular, the economic analysis of law can be assigned to that new 
institutionalism (Institutional Choice) which describes and analyses the institutions of state and society and assesses them under the criterion of allocative efficiency or whether other goals are achieved, such as the protection of human rights or the reduction of inequality.

Institutionalism distinguishes between various social control mechanisms through which the use of resources can be directed: ${ }^{5}$

1. the market, which coordinates the decentralised decisions of individuals by transactions based on prices;

2. the bureaucratic process of coordinating individual decisions within hierarchical organisations through orders along vertical chains;

3. the political decision-making mechanism that coordinates individual decisions based on elections and votes;

4. the process of bargaining, in which individuals form groups that negotiate with each other.

This list is not exhaustive, as there are other methods, such as auctions or races (for example, for patents), by means of which resource allocation is carried out, some of whose effects are significantly different from those mentioned above.

These procedures or institutional arrangements may be combined with each other. The task of a political economist can be seen in proposing that combination of institutions which minimises the degree of resource waste, whilst taking into account individual preferences. Legal norms, in turn, describe the concrete structure of a social mechanism and the interlocking in the institutional arrangement, which often consists of a mixture of different institutions.

For example, market outcomes in a strict liability system will be different from those in a negligence system. The same applies if, in one case, a resource is subject to legal restrictions (for example, prohibition of development), whilst in another case this restriction does not exist. The question is then always whether the results of such regulations correspond to the preferences of the members of the society and whether they create a state which supports the individual objectives of the members of a society.

\subsection{ECONOMIC ANALYSIS AND TRADITIONAL MICROECONOMICS}

An important branch of traditional microeconomic theory has been to describe the precise conditions under which a society reaches the state of allocative efficiency where waste becomes zero. These conditions are collectively summarised by the term "perfect competition". A perfectly competitive market based on freedom of contract will achieve a state of zero waste. In reality, none of the numerous conditions for perfect competition is ever fulfilled. This model is rather a reference system against which the performance of real social institutions, markets, bureaucracies or mixed systems can be compared.

See Richter R, Furubotn EG (2005) Institutions and Economic Theory: The Contribution of the New Institutional Economics. Voigt S (2019) Institutional Economics: An Introduction. 
The theory of perfect competition presupposed - without any awareness or explicit inclusion in the theory - a specific legal framework. It regarded the resources of a society as "physical units" whose physical characteristics determine their usefulness and price. This is not the case, however, because the use of goods is co-determined by a variety of legal positions, by rights of action and sanctions for the violation of norms. Hence their usefulness and price also depend on legal norms. Awareness of this fact led to a change in the approach to the problem in microeconomics. The question has now been raised as to how changes in the legal arrangement affect allocative efficiency, for example the transition from negligence to strict liability, or the replacement of a private entitlement for an injunction by a claim for damages or the control of general terms and conditions.

In a ground-breaking paper titled "The Problem of Social Cost" (1960) Ronald Coase ${ }^{6}$ provided an answer to this question in general terms. He demonstrated that transferable alternative legal positions do not affect the efficiency and nature of resource utilisation, when transaction costs, i.e. the costs that potential contractors have to incur for information and coordination in order to conclude the contract, and the costs of enforcement are zero. Regardless of the concrete form of a legal system, efficient use of resources always prevails under these conditions. This concept of transaction costs stimulated a wealth of individual studies on the effects of legal norms. For whenever transaction costs are greater than zero or even prohibitively high - for example, between tortfeasor and injured party in accident law the concrete form of a legal norm is of considerable importance for the efficient allocation of resources.

Thus, on the basis of an extended microeconomics, a wealth of studies on contract law, tort law, environmental law, consumer law, patent law, corporation law etc. appeared, which in their entirety are referred to as the economic analysis of law or "law and economics"?

\subsection{RELATIONSHIP BETWEEN ALLOCATIVE EFFICIENCY AND EQUITY}

When asking the question about the relationship between efficiency and justice, it is necessary to point out misunderstandings that burden communication between lawyers and economists. It is equally important to recognise that the rules of a desirable human coexistence cannot be based solely on the goal of efficiency. To avoid misunderstandings, the following should be noted: the economic concept of allocative efficiency has nothing to do with the associations of the concept of "efficiency" in everyday use. Efficiency is not a secondary virtue, but an elemen-

\footnotetext{
6 Coase R (1960) The Problem of Social Cost. Journal of Law and Economics 3:1 et seq.

7 The following journals are of particular importance for the development of "law and economics": Journal of Law and Economics, Journal of Legal Studies, Journal of Law, Economics and Organization, International Review of Law and Economics, Review of Law and Economics, Journal of Institutional and Theoretical Economics (formerly published as Zeitschrift für die gesamte Staatswissenschaft), European Journal of Law and Economics, Journal of Empirical Legal Studies, and American Law and Economics Review.
} 
tary imperative for state action and for the construction of social institutions. ${ }^{8}$ A society is efficient if, based on a given distribution of wealth, it brings about a state in which no one can be made better off without making someone else worse off. Hence, all possibilities are exhausted to put someone in a better position without putting someone else in a worse position. Resources are thus utilised in a socially most useful manner. ${ }^{9}$ A society with efficiency-enhancing legal norms does not yet have to be fair. It may be necessary to accept efficiency losses in order to achieve higher-value normative goals. However, a consistently inefficient society is unjust in any event. It makes little difference to a starving person in Africa if he is told that his poverty is not primarily based on inequality of distribution, but on an inefficient institutional arrangement that prevents the entitlement to urgently needed food. And it will be of little consolation to a long-term unemployed person in Europe, who has no chance of finding a job because of the inflexibility and institutional rigidities of capital, labour and goods markets, even though he or she lives in a country which ranks at the top of the international income scale and his income from welfare payments is still high in international comparison.

Therefore, if the creation of allocative efficiency is one of the essential requirements of a legal system, it is not easily justified if legal objectives such as security of business and legal certainty are ranked equally or above the efficiency objective. They are legitimate if they promote allocative efficiency. It is not justifiable, for example, to maintain case law that leads to inefficient solutions solely on the grounds of legal certainty if its modification leads to significant efficiency gains. For example, it would be unjustifiable to maintain the scope of road safety obligations at a constant level solely on the grounds of legal certainty if a society is undergoing profound economic developments. An example would be the advancement from a poor agrarian state to a rich industrial nation.

\subsection{EQUITABLE DISTRIBUTION AND EFFICIENCY}

Efficiency is compatible with a state of unjust distribution. For this reason, distributive justice is a further objective alongside allocative efficiency.

Many representatives of the economic analysis agree that redistribution is necessary, ${ }^{10}$ i.e. that the market mechanism does not lead to a fair distribution of the societal wealth as

8 This view has gained ground among lawyers. See Fleischer H (2008) Effizienz als Regelungsziel im Handelsund Wirtschaftsrecht [Efficiency as Policy Target in Commercial and Economic Law].

9 Buchanan calls this "efficient (benefit maximizing or loss minimizing) allocation of resources" in: (1985) Rights, Efficiency and Exchange: The Irrelevance of Transaction Costs. In: Neumann M (ed.) Ansprüche, Eigentumsund Verfügungsrechte. Schriften des Vereins für Socialpolitik. pp. 9 et seq., p. 11.

10 Sanchirico CW (2000) Taxes versus Legal Rules as Instruments of Equity: A More Equitable View. Journal of Legal Studies 29:797. Kaplow L, Shavell S (1994) Why the Legal System is Less Efficient than the Income Tax in Redistributing Income. Journal of Legal Studies 23:667. v. Weizsäcker (1983) Was leistet die Property Rights - Theorie für aktuelle wirtschaftspolitische Fragen? [What Does Property Rights Theory Contribute to Current Questions of Economic Policy?] In: Neumann M (ed.) Ansprüche, Eigentums- und Verfügungsrechte. Schriften des Vereins für Socialpolitik. pp. 123 et seq., p. 125. 
a whole. However, the demand that the disadvantaged should be compensated for every efficiency-enhancing measure is commonly rejected, Similarly, it should be rejected to accept high efficiency losses for reasons of distribution policy, for example, through rent ceilings for housing or through state price ceilings for agricultural goods. As a rule, there is a demand for efficiency and distributive justice to be achieved by different, independent social institutions. Redistribution is always associated with certain efficiency losses.

Okun ${ }^{11}$ uses the image of a water bucket with a hole. Redistribution from the rich to the poor is like pouring water from a full bucket into an empty bucket with a hole in it. Fewer resources reach the recipients than is initially taken from the rich. It is thus important to find buckets with small holes.

This cannot succeed if the legal norms designed for the management of resources are generally to perform additional redistribution tasks. It is better to construct separate legal arrangements for each of these tasks.

\subsection{ALTERNATIVES TO THE EFFICIENCY CRITERION}

There are a large number of legal policy demands that seem to be an alternative to the efficiency criterion without actually being it. Others are compatible, albeit not identical, with the efficiency criterion, and still others may be in direct opposition to the efficiency criterion.

\section{EXAMPLE 0.2}

\section{CONSUMER PROTECTION}

Legal norms that strengthen the legal position of the consumer are often regarded as a zero-sum game. On the one hand there is the consumer, on the other there are the suppliers of goods. What you give to one, you take away from the other. This view is wrong, because any improvement in the legal position of the consumer that causes costs is reflected in the price of the goods. The conflict we are talking about here is ultimately taking place in the minds of consumers themselves. It is necessary to ask whether they would prefer to have a lower price or a better legal position in the event of defective performance. If the latter is the case and the market does not reflect this preference - for example in general terms and conditions - a change in the legal arrangement is efficient in terms of consumer protection, otherwise it is not. Constructing a contrast between efficiency and the demand for consumer protection is therefore unjustified.

\section{ENVIRONMENTAL PROTECTION}

Similar considerations apply to environmental law. The problem of environmental law is to find legal arrangements that achieve the level of environmental protection that the members of a society want to have, whilst taking into account the costs of environmental protection and excluding the external effects of such production activities which cannot be internalised in the costs. If this situation is achieved, it can be called efficient envi-

11 Okun A (1975) Equality and Efficiency, The Big Trade-off. 
ronmental protection. There is no conflict between economy and ecology in this respect. This keyword may be useful for describing specific conflicts of interest that arise from the existence of inefficient environmental legislation. It is completely unsuitable for the search for environmental standards based on the individual preferences of members of society.

\section{REDUCTION OF DISCRIMINATION}

The avoidance of religious, racial or gender discrimination is an imperative of justice, which is not identical with allocative efficiency, but in many cases is promoted by allocative efficiency. If an institutional arrangement ensures that a job is always filled by the most qualified person, this is efficient. It also rules out racial discrimination, as an example. Many highly qualified Jewish professors had to vacate their chairs in 1933 to make way for those political opportunists who had no resonance. It can be said that this discrimination was made possible by an inefficient institutional arrangement of the universities.

\section{DEMOCRATISATION}

If a democratic society is understood to be one in which each individual can assert the highest degree of his or her own interests whilst being compatible with the interests of others, there is no contradiction between democratisation and allocation efficiency. Both are mutually dependent. Sometimes, however, democratisation of society is understood to be a process in which the number of decisions taken by majority vote increases. This process may well contrast with allocative efficiency, for example when the market is a more efficient system for coordinating individual preferences than a political voting system. In terms of allocative efficiency, it would, for example, not make sense to determine the number and design of different types of passenger cars by means of a referendum. Voting processes have no value on their own but must be legitimised by the fact that they succeed better than other procedures in mapping and aggregating individual preferences.

\section{RESTRICTION OF ECONOMIC POWER}

Economic power usually also leads to the misallocation of resources, not just to the redistribution processes in favour of the powerful. If a monopolist sets the price of his goods permanently above the competitive price, this leads to "wrong" prices that send the wrong signals to buyers. This also produces inefficient quantities of output, which is just another expression of wastefulness. In this respect, social arrangements are initially only efficient if they largely limit the number and scope of economic power positions. If this fails, it may be necessary - also in terms of allocative efficiency - to build up countervailing power positions or to legally limit power. The legal protection of those who are disadvantaged by positions of power is thus also a requirement of the demand for allocative efficiency, not only of distributive justice.

\section{PROTECTION OF THE WEAK}

The protection of the weak can but does not always have to be consistent with the goal of allocative efficiency. If a mentally ill person or a child cannot conclude effective contracts, this regulation serves to protect them. However, the alternative would also be inefficient, because valid contracts of a mentally ill person would very likely result in those resources which are at the disposal of the mentally ill person not to flow to the place where they 
would be most useful. There are, however, cases in which the protection of the weak can conflict with allocative efficiency; for example, the obligation to provide information about one's own person in an application. There is certain information about the applicant, the knowledge of which would enable the employer to place the employee where his contribution to the overall product is highest. This would be efficient.

However, in order to protect human dignity (Article 1 of the Basic Law), it may be necessary to prohibit the question of certain personal characteristics or not to legally sanction their incorrect answer. This also applies if this provision is associated with an efficiency loss. In this regard one is bound to reach limits. After all, there are recognised standards in every society, and their enforcement takes place even if they are incompatible with the efficiency objective.

\section{INALIENABLE RIGHTS}

In his book "The Selfish Gene"12 Dawkins shows the behaviour of penguins standing on the rocky cliff and hesitating to jump into the water. On the one hand they find food there, on the other hand there is the danger of being eaten by seals. In this situation some penguins push another down and observe what happens. If the other is not eaten, they also jump. This genetically programmed behaviour minimises the number of penguins eaten by seals. It is therefore efficient.

However, such institutional arrangements would not be accepted as fair in a human society, despite their efficiency. Where they still occur, they are considered to be the low points of human civilisation. This applies, for example, to the decision of the Argentine military junta to fight terrorism by murdering all members of left-wing groups. It also applies to the lethal hypothermia experiments carried out in Dachau during the Second World War using prisoners of war, which were carried out for the benefit of German airmen shot down over the North Sea. It would never justify such measures if it could be proved that they increased the total number of survivors.

There are less dramatic cases where possible losses of efficiency are accepted. For example, the owner of a department store has no right to search the cars or even the homes of all employees in the case of an unspecific suspicion of theft. Even a corresponding contractual agreement between employer and employee would be immoral and therefore void.

12 Dawkins R (1976) The Selfish Gene. 4th edn. 2016. p. 6. 


\subsection{TASK DESCRIPTION OF THE ECONOMIC ANALYSIS OF LAW}

The economic analysis of law does not consider legal norms as part of an invariable set of data. It includes the legal system itself in the economic analysis by conceiving the legally constituted powers of action as variables. This approach leads to the following tasks: ${ }^{13}$

1. the establishment of an existing legal structure as well as the type and distribution of legal powers of action;

2. the impact that the legal structure has on the objective of allocative efficiency;

3 . the actual conditions for the development of an efficient legal structure;

4. how the legal structure should be designed with regard to the objective of allocative efficiency.

The present book refers mainly to tasks (2) and (4) and presents the economic approach for important areas of civil law. ${ }^{14}$ Special emphasis is placed on the possible significance of this research area for case law and doctrine. From a jurisprudential perspective, the aim is to present changes in case law and legal dogma, to reveal their normative justifications and to question the extent to which the problems can be better addressed by economic analysis, but also where their limits lie in the process of applying the law. Throughout this book we agree with the insight of Pargendler and Salama on the role of economics for civil law countries. "given the ever-greater role of courts in the formulation of public policies, the application of legal principles and rules increasingly calls for a theory of human behavior ... to help foresee the likely aggregate consequences of different interpretations of the law". This is consistent with the traditional role of civilian legal scholarship in providing guidance for the application of law by courts. ${ }^{15}$

\subsection{ABOUT THE STRUCTURE OF THE BOOK}

The book is divided into five parts and a total of 25 chapters. After an introductory basic part, the second, third and fourth parts follow with an economic analysis of tort law, contract law as well as property and ownership of similar legal positions. The volume concludes with a chapter on company law.

13 Cf Furubotn E, Pejovich S (1974) The Economics of Property Rights. See especially Demsetz H (1974) Toward a Theory of Property Rights. In Gopalakrishnan C (ed.) (1974) Classic Papers in Natural Resource Economics. pp. 163 et seq.

14 See also Posner R (2011) Economic Analysis of Law. 8th edn. Cooter R, Ulen T (2012) Law and Economics. 6th edn.

15 Pargendler M, Salama BM (2015) Law and Economics in the Civil Law World: The Case of Brazilian Courts. Tulane Law Review, 90:439. 
The economic analysis deals with consequence-orientated action. It is now widely accepted that lawyers - perhaps more so today than in the past - have to rethink the consequences of their decisions. For example, legally binding norms are constantly being set by the highest judicial decision-making bodies. ${ }^{16}$ In Part I, therefore, the first chapter describes the conditions under which consequence-orientated decision-making is possible after all. In particular, it is emphasised that for consequence-orientated decision-making, a forecast of the consequences of action and an independent evaluation of the consequences of action are always necessary. In the second chapter, the problem of impact assessment is systematically scrutinised. The concepts of allocative efficiency and the corresponding normative criteria are presented in the light of welfare economics and economic ethics. Finally, the third chapter introduces the prognostic approach of microeconomic theory as well as the theory of property rights and the economic analysis of law. In the fourth chapter, the approach of behavioural economics is examined in detail with regard to its effects on the premises underlying the economic analysis of law and on the resulting restrictions on the general freedom of action through paternalistic interventions including nudging.

Part II deals with the economic analysis of tort law. First, the objectives of tort law are described from an economic and legal perspective. This is followed by a description of the essential effects of strict liability and strict liability for fault, whereby the economic and legal-doctrinal explanations are closely related. Subsequently, problems of bilateral damages, where not only the tortfeasor but also the injured party can ward off the damage, are examined.

Problems of causality are subsequently dealt with. Special emphasis has been placed on clarifying the issues arising from the limitation of damages by liberal rights and also from difficulties in assessing the damages. This is followed by a presentation of three important individual areas of tort law, namely producer liability, liability for environmental damage and liability for personal injury. In addition, problems are examined that lie in the border area between civil liability and public law safety regulation. It also addresses the question of the extent to which the analysis changes when results of behavioural research are taken into account, when either parties or courts behave inconsistently or in an unselfish manner.

The third part deals with contractual and pre-contractual legal positions. First we describe the economic functions of the contract and contract law and important contractual legal positions. Based on the idea of a "fully specified" contract, economic criteria for the judicial control of contractual relationships are developed. Special emphasis is placed on the elimination of the basis of the contract, on impossibility and default or breach of contract as well as on warranty law. In particular, the extent to which actual case law either follows economic criteria or could be based thereon, will be examined.

Furthermore, problems of behaviour in cases of uncertainty and ignorance and the social and legal institutions that help to overcome such problems are examined. In particular, the

16 Kübler F (1983) Was leistet die Konzeption der Property Rights für aktuelle rechtspolitische Probleme? [What Does Property Rights Theory Contribute to Current Questions of Legal Policy?] In: Neumann M (ed.) Ansprüche, Eigentums- und Verfügungsrechte. Schriften des Vereins für Socialpolitik. pp. 105 et seq., esp. p. 108. 
degree to which such institutions - for example, relationships of trust - should be legally protected if an economic approach is followed, will also be scrutinised.

The fourth part initially discusses different forms of property rights in the sense of absolute rights and their economic effects. This is followed by an economic analysis of the forced transfer of property rights, such as acquisition in good faith, or expropriation or transfer of property rights in the event of bankruptcy. In addition, problems of incompatible land use and the relevant legal rules in this context are examined. The fourth part ends with a presentation of the most important rules of intellectual property law and their economic function. In particular, it is emphasised that while a "Tragedy of the Commons" has arisen in the absence of intellectual property rights, the introduction and constant expansion of industrial property protection has led to a "Tragedy of the Anti-commons" with the danger of repealing the productive effects of patent and copyright law. There is hardly any field of law in which the consequences of legal norms are as unclear as in patent and copyright law. The question of whether the "numerus clausus" of rights vis-à-vis everyone hinders the development of new legal forms is also being investigated.

The fifth and final part relates to business organisations and the economic analysis of networks and corporation law. It deals with the central principal-agent problems that arise in the company between employees, management, majority and minority shareholders as well as lenders, and the means by which they can be mitigated legally. Special emphasis is placed on the presentation of that research which shows why, on the one hand, the form of the legal entity in conjunction with limited liability has had and continues to have a prominent significance for economic development, without which neither large private enterprises nor liquid capital markets could exist and why, on the other hand, it is particularly susceptible to abuse. New types of contracts are also treated as symbiotic contracts, which exist between the market and hierarchical organisation. 